\title{
PERAN PEKERJA SOSIAL DALAM PROSES REINTEGRASI KORBAN PENYALAHGUNAAN NAPZA DI IPWL BUMI KAHEMAN KABUPATEN BANDUNG
}

\author{
Siti Fatimah Azzahroo \\ Politeknik Kesejahteraan Sosial Bandung, sfazzahroo@gmail.com \\ Ellya Susilowati \\ Politeknik Kesejahteraan Sosial Bandung, ellyasusilowati@gmail.com \\ Emilia Hambali \\ Politeknik Kesejahteraan Sosial Bandung, emiliahambali@yahoo.co.id
}

\begin{abstract}
This study aims to obtain an in-depth description of "The Role of Social Workers in the Reintegration Process of Drug Abuse Victims at the Bumi Kaheman Report Recipient Institution (IPWL), Bumi Kaheman, Bandung Regency". The approach used in this research is qualitative with descriptive methods. Data collection techniques used were in-depth interviews with two main informants and two supporting informants, observation and documentation study. The aspects examined in this study are the role of social workers in preparing for reintegration, assessing the reintegration process, planning reintegration implementation, implementing reintegration and ending reintegration of drug abuse victims. The results of this study indicate that the role of social workers in the process of reintegration of drug abuse victims in IPWL Bumi Kaheman has been carried out in each process by meeting the implementation of activities in client preparation and family preparation and carrying out nine roles, including the role of facilitator, educator, facilitator, planner. , negotiators, intermediaries, defender, case managers, and administrator. However, it is still found that the role of social workers is not optimal in preparing the community for the reintegration process due to several factors, namely the limited funds owned by the institution and the spread of clients in various locations which are quite difficult to reach so that there is no implementation of community preparation. The program recommendation for this problem is "Capacity Building of Social Worker Institutions in Preparing Communities for the Reintegration Process of Drug Abuse Victims through the Educational Group ".
\end{abstract}

Keywords:Tthe Role of Social Worker, Reintegration Process, Drug Abuse

\section{Abstrak}

Penelitian ini bertujuan untuk memperoleh gambaran secara mendalam tentang "Peran Pekerja Sosial Dalam Proses Reintegrasi Korban Penyalahgunaan NAPZA Di 
Institusi Penerima Wajib Lapor (IPWL) Bumi Kaheman Kabupaten Bandung”. Pendekatan yang digunakan dalam penelitian ini adalah kualitatif dengan metode deskriptif. Teknik pengumpulan data yang digunakan adalah wawancara mendalam kepada dua informan utama dan dua informan pendukung, observasi serta studi dokumentasi. Aspek yang diteliti dalam penelitian ini adalah peran pekerja sosial dalam persiapan reintegrasi, melakukan asesmen pada proses reintegrasi, melakukan perencanaan pelaksanaan reintegrasi, pelaksanaan reintegrasi dan pengakhiran reintegrasi korban penyalahgunaan NAPZA. Hasil penelitian ini menunjukkan bahwa peran pekerja sosial dalam proses reintegrasi korban penyalahgunaan NAPZA di IPWL Bumi Kaheman sudah dilakukan di setiap prosesnya dengan ditemuinya pelaksanaan kegiatan pada penyiapan klien dan penyiapan keluarga serta dilaksanakannya sembilan peran yang di antaranya adalah peran sebagai fasilitator, pendidik, pemungkin, perencana, perunding, perantara, pembela, manajer kasus dan administrator. Namun hal tersebut masih ditemukan belum optimalnya peran pekerja sosial dalam penyiapan masyarakat pada proses reintegrasi dikarenakan oleh beberapa faktor yaitu keterbatasan dana yang dimiliki lembaga dan tersebarnya klien di berbagai macam lokasi yang cukup sulit untuk di jangkau sehingga tidak terjadinya pelaksanaan penyiapan masyarakat. Rekomendasi program untuk permasalahan ini adalah "Peningkatan Kapasitas Lembaga Pekerja Sosial dalam Penyiapan Masyarakat Pada Proses Reintegrasi Korban Penyalahgunaan NAPZA Melalui Educational Group".

Kata Kunci: Peran Pekerja Sosial, Proses Reintegrasi , Korban Penyalahgunaan NAPZA

\section{PENDAHULUAN}

Seiring dengan perkembangan zaman penyebaran NAPZA terus berkembang, masalah penyalahgunaan NAPZA di Indonesia telah meluas dan sangat mengkhawatirkan, tidak saja di perkotaan, melainkan juga menjangkau ke perdesaan. Indonesia sebagai negara kepulauan dan memiliki jumlah populasi penduduk yang sangat besar, menjadikan negara ini sebagai sasaran empuk untuk melakukan peredaran gelap NAPZA. Tak heran jika Indonesia sudah memasuki darurat NAPZA, sebab berdasarkan data BNN tahun 2017, prevalensi penyalahgunaan narkoba/NAPZA secara nasional mencapai 1,77 persen atau sekitar 3,37 juta jiwa, dengan persentase rata-rata pengguna, 59 persen kelompok pekerja atau produktif berpenghasilan, dan 24 persen sisanya merupakan kelompok pelajar (jabar.tribunnews.com).

Data terbaru bahwa pada tahun 2019 ada 646 ribu orang di Provinsi Jawa Barat yang menggunakan narkoba dan untuk di Kabupaten Bandung jumlah orang yang terindikasi ada sekitar 28 ribu orang kecanduan narkoba dan kemudian Provinsi Jawa Barat melaju dengan menempati posisi urutan pertama di seluruh Indonesia (republika.co). Melihat dari data yang ada bahwa akibat dari penyalahgunaan narkoba negara mengalami kerugian. Pada dasarnya penggunaan NAPZA dapat memberikan dampak negatif bagi pemakainya baik secara fisik, psikis maupun sosial. Kondisi yang di alami korban penyalahgunaan NAPZA tentunya memicu terhambatnya keberfungsian 
sosial. Korban penyalahgunaan NAPZA tentunya perlu tindakan agar terlepas dari jerat NAPZA, sehingga mampu melaksanakan fungsi sosialnya dengan baik. Rehabilitasi sosial merupakan salah satu solusinya.

Proses rehabilitasi sosial menurut Peraturan Menteri Sosial Republik Indonesia Nomor 26 Tahun 2012 Tentang Standar Rehabilitasi Sosial Korban Penyalahgunaan Narkotika, Psikotropika dan Zat Adiktif Lainnya terdiri dari atas 7 (tujuh) tahapan yang meliputi tahap pendekatan awal/tahap persiapan rehabilitasi, tahap pengungkapan dan pemahaman masalah, tahap penyusunan rencana pemecahan masalah, tahap pemecahan masalah, tahap reintegrasi, tahap terminasi dan tahap bimbingan lanjut. Dalam J.P Chaplin (2002:101) reintegrasi merupakan suatu upaya yang bertujuan untuk membaurkan kembali seseorang ke dalam lingkungan sosialnya baik pribadi, anggota keluarga maupun anggota masyarakat. Selain itu reintegrasi sosial juga merupakan proses penyatuan kembali individu/kelompok ke dalam masyarakat luas untuk dapat melangsungkan hidup secara umum (United Nations 2012)

Proses reintegrasi sosial cukup penting dilakukan karena menyangkut keberlangsungan hidup maupun keberfungsian sosial para korban penyalahgunaan NAPZA. Hal ini dilihat dari hasil penelitian Hari Harjanto dkk (2018:79) terkait reintegrasi menunjukkan bahwa tingkat hubungan terbesar dalam membentuk kesiapan reintegrasi klien adalah kontrol perilaku yang dibentuk oleh kemampuan diri, peran lembaga, peran pekerja sosial dan peran konselor.

Kementrian Sosial memiliki program yang Institusi Penerima Wajib Lapor (IPWL) yang dikelola oleh masyarakat sebagai lembaga Kesejahteraan Sosial NAPZA untuk memberikan rehabilitasi sosial kepada penyalahguna NAPZA (Susilowati.E, ttps://www.researchgate.net/publication/34223 108h7). Salah satu IPWL di Jawa Barat adalah IPWL Bumi Kaheman di Kabupaten Bandung yang memberikan pelayanan dalam penyalahgunaan NAPZA.

Beberapa kondisi residen yang melakukan rehabilitasi di IPWL Bumi Kaheman memiliki prasangka dan anggapan belum siap untuk kembali ke masyarakat. Prasangka dan anggapan tersebut tentunya mempengaruhi pembentukan kesiapan reintegrasi klien, maka peneliti ingin mengetahui gambaran secara empiris tentang peran pekerja sosial dalam proses reintegrasi korban penyalahgunaan NAPZA di lembaga IPWL Bumi Kaheman.

Istilah peran dalam Kamus Besar Bahasa Indonesia "mempunyai arti pemain sandiwara (film), tukang lawak pada permainan makyong, perangkat tingkah yang diharapkan dimiliki oleh orang yang berkedudukan di masyarakat" (Departemen Pendidikan Nasional, 2005). Bauer berpendapat bahwa peran (dalam Haris, 2012) "sebagai presepsi mengenai cara orang itu diharapkan berperilaku atau kesadaran mengenai pola perilaku atau fungsi yang diharapkan dari orang tersebut". Adapun dalam pengertian lain bahwa peran adalah suatu fungsi yang diharapkan dari seseorang yang sedang memegang jabatan. Jadi, suatu peran yang menyebabkan perilaku seseorang memiliki pengaruh dalam menjalankan fungsinya. Sedangkan, Pekerja sosial menurut Siporin dalam Fahrudin adalah "metode kelembagaan sosial untuk membantu orang mencegah dan memecahkan masalahmasalah sosial mereka, untuk memulihkan dan meningkatkan keberfungsian sosial mereka" (2012:61). 
Persoalan penyalahgunaan NAPZA bukan hanya menyangkut aspek biologis dan fisik tetapi menyangkut aspek penting lainnya seperti psikologis dan sosialnya. Realitas tersebut menuntut peran para pekerja sosial melalui intervensi terhadap permasalahan sosial dan emosional korban penyalahgunaan NAPZA. Pekerja sosial mempunyai peran yang tentunya sangat penting bagi masalah NAPZA dalam penyelesaiannya yang tercakup dalam proses pertolongan.

Berdasarkan latar belakang di atas peneliti tertarik untuk meneliti terkait Peran Pekerja Sosial dalam Proses Reintegrasi Korban Penyalahgunaan NAPZA di Institusi Penerima Wajib Lapor (IPWL) Bumi Kaheman Desa Bandasari Kecamatan Cangkuang Kabupaten Bandung.

\section{METODE}

Metode penelitian yang digunakan adalah metode desain deskriptif dengan pendekatan kualitatif. Penelitian deskriptif ini bertujuan untuk menggali informasi, memotret situasi sosial dan mengeksplorasi secara lebih dan menyeluruh serta lebih luas mengenai Peran Pekerja Sosial Dalam Proses Reintegrasi Korban Penyalahgunaan NAPZA Di Institusi Penerima Wajib Lapor (IPWL) Bumi Kaheman Kabupaten Bandung. Penelitian kualitatif merupakan penelitian yang menghasilkan data deskriptif berupa kalimat tertulis yang di dasari oleh lisan atau perkataan dari informan dan perilaku yang dapat diamati. Teknik pengumpulan data dalam penelitian ini menggunakan teknik wawancara mendalam, dan studi dokumentasi.

Penentuan informan dengan menggunakan purposive, berjumlah 4(empat) informan. Sumber data dalam penelitian ini adalah sumber data primer dan sumber data sekunder. Sumber data primer diambil dari dua orang pekerja sosial yang bekerja di IPWL Bumi Kaheman. Sedangkan sumber data sekunder diperoleh dengan mempelajari profil IPWL, tupoksi IPWL, landasan hukum IPWL, serta mempelajari informasi lainnya dari tokoh maupun pihak lainnya yang terkait. Informan pendukung dalam penelitian ini merupakan satu orang konselor adiksi IPWL Bumi Kaheman dan satu orang korban penyalahgunaan NAPZA atau residen yang sudah cukup lama berada di IPWL Bumi Kaheman yang mampu berkomunikasi secara dua arah.

\section{HASIL PENELITIAN}

Hasil penelitian memuat tentang karakteristik informan, persiapan reintegrasi, asesmen pada proses reintegrasi, perencanaan pelaksanaan reintegrasi, pelaksanaan reintegrasi, pengakhiran reintegrasi, dukungan yang didapatkan pekerja sosial, hambatan yang dihadapi pekerja sosial dan harapan pekerja sosial terhadap proses reintegrasi. Berikut merupakan penjelasan dari hasil penelitian yang telah dilakukan oleh penelliti.

\section{Karakteristik Informan Penelitian}

Informan dalam penelitian ini berjumlah sebanyak empat orang. Seluruh informan yang ada yakni terdiri dari informan utama di mana di antaranya dua orang pekerja sosial lalu informan pendukung yang terdiri dari dua orang, yang keduanya merupakan satu orang konselor adiksi dan satu orang korban penyalahgunaan NAPZA atau residen yang sudah lama berada di IPWL Bumi Kaheman yang dapat berkomunikasi secara dua arah. Berikut ini, peneliti berikan gambaran ringkas identitas informan dalam penelitian melalui tabel: 
Tabel 1 Karakteristik Informan

\begin{tabular}{|c|c|c|c|c|c|}
\hline Inisial & Usia & Pend & Kerja & Status & $\begin{array}{l}\text { Pelatihan yang } \\
\text { pernah diikuti }\end{array}$ \\
\hline DJ & 36 & DIV & $\begin{array}{l}\text { Pekerja } \\
\text { Sosial } \\
(4 \\
\text { tahun) }\end{array}$ & Petugas & $\begin{array}{l}\text { Diklat Peksos } \\
\text { Rehabsos NAPZA } \\
\text { selama } 14 \text { hari yang } \\
\text { diselenggarakan oleh } \\
\text { Badiklit Pansos } \\
\text { Kemensos }\end{array}$ \\
\hline IS & 51 & $\mathrm{~S} 1$ & $\begin{array}{l}\text { Pekerja } \\
\text { Sosial } \\
\text { (5 tahun) }\end{array}$ & Petugas & $\begin{array}{l}\text { Bimbingan Teknis } \\
\text { Pelaksanaan Tugas } \\
\text { Pokok Peksos di } \\
\text { IPWL selama } 17 \text { hari } \\
\text { dan Diklat Peksos } \\
\text { Rehabsos NAPZA } \\
\text { selama } 4 \text { hari yang } \\
\text { diselenggarakan oleh } \\
\text { Badiklit Pansos } \\
\text { Kemensos }\end{array}$ \\
\hline $\mathrm{R}$ & 28 & D3 & $\begin{array}{l}\text { Konselor } \\
(10 \\
\text { tahun) }\end{array}$ & Petugas & $\begin{array}{l}\text { Pendidikan dan } \\
\text { pelatihan sebagai } \\
\text { konselor adiksi } \\
\text { rehabilitasi NAPZA } \\
\text { yang diselenggarakan } \\
\text { oleh BBPPKS. }\end{array}$ \\
\hline A & 45 & SMA & $\begin{array}{l}\text { Pegawai } \\
\text { Pabrik } \\
\text { (berada } \\
\text { di IPWL } \\
6 \text { tahun) }\end{array}$ & KPN & - \\
\hline
\end{tabular}

Berdasarkan karakteristik pekerja sosial tersebut diketahui bahwa pekerja sosial adiksi di IPWL Bumi Kaheman melaksanakan perannya sebagai pekerja sosial dalam proses reintegrasi korban penyalahgunaan NAPZA. Hal ini dikarenakan lamanya pekerja sosial bekerja di IPWL Bumi Kaheman, pengalaman bekerja pekerja sosial dan latar belakang pendidikan yang ditempuh maupun pelatihan yang diikuti serta banyaknya jumlah klien yang ditangani oleh pekerja sosial adiksi.

\section{Persiapan Reintegrasi}

Persiapan reintegrasi terhadap penyiapan klien ditemukan bahwa pekerja sosial melakukan pemberian materi, pemberian terapi dan pelatihan vokasional. Materi yang dipersiapkan oleh pekerja sosial dalam persiapan reintegrasi ini tidak memiliki acuan baku atau acuan khusus. Penyiapan materi dalam penyiapan reintegrasi di antaranya ada psikoedukasi yakni yang mencakup penyiapan materi terkait NAPZA, bahaya penggunaan NAPZA, pemahaman rehabilitasi sosial serta menyiapkan materi untuk memberikan pemahaman bahwa permasalahan penyalahgunaan NAPZA merupakan masalah sosial. Kemudian penyiapan materi kemampuan bertahan hidup yakni yang mencakup keterampilan menyelesaikan permasalahan (coping skills dan problem solving), cara bersosialisasi kembali dan bertahan hidup di lingkungan sosialnya. Lalu yang terakhir memberikan keterampilan dengan menyiapkan kegiatan vokasional seperti berternak, bercocok tanam, membuat gitar dan mempersiapkan keterampilan membuat kerajinan. Selain melakukan pemberian materi dan pelatihan keterampilan, pekerja sosial juga menyiapkan klien dengan pemberian terapi guna membantu dan mengubah perilaku klien. Penyiapan keluarga pada tahap persiapan reintegrasi berdasarkan kedua informan dilakukan dalam bentuk kegiatan homevisit dan family support group. Selebihnya pekerja sosial melakukan kunjungan rumah dengan menghubungi keluarga melalui telekomunikasi. Selain itu pekerja sosial dalam hal ini tetap melakukan perencanaan dan persiapan yang di antaranya yakni melakukan pendataan keluarga klien yang di mana klien sudah memasuki tahap reintegrasi, menentukan tempat kegiatan pertemuan dengan keluarga klien, melaksanakan pertemuan dengan pegawai lainnya, pemilihan materi yang akan di sampaikan di forum pertemuan, persiapan undangan kepada keluarga klien.

\section{Asesmen Pada Proses Reintegrasi}

Asesmen yang dilakukan pekerja sosial pada keluarga yakni dengan mengajukan pertanyaan verbal atau wawancara melalui tatap muka maupun media telekomunikasi dan observasi hubungan keluarga dengan klien. Hal ini terlihat dari informan DJ yang lebih 
mengutamakan efisiensi dan efektivitas dalam asesmen yang dilakukannya dalam reintegrasi korban penyalahgunaan NAPZA dengan melakukan wawancara melalui media telekomunikasi dibandingkan informan IS yang terkadang lebih menyempatkan kunjungan rumah keluarga klien agar mampu mempersiapkan reintegrasi lebih dengan rencana yang lebih matang. Namun, informan IS hanya dapat melakukan kunjungan rumah jika waktu memungkinkan dan wilayah yang didatangi searah dengan jalan arah pulang informan IS. Selain itu mengobservasi hubungan keluarga dengan klien melalui kegiatan kunjungan yang dilakukan keluarga ketika ke lembaga IPWL

\section{Perencanaan Pelaksanaan Reintegrasi}

Hal yang direncanakan oleh pekerja sosial dalam proses reintegrasi ini mencakup banyak hal. Tentunya persiapan lebih berfokus pada klien dan keluarga klien yang mencakup persiapan mental keluarga untuk tidak memberi stigma negatif kepada klien, mempersiapkan keluarga dengan memberi edukasi tentang cara mengatasi ataupun menangani kekambuhan, mempersiapkan materi yang mencakup informasi dan pengetahuan untuk keluarga klien, mempersiapkan keterampilan klien, menghubungkan klien dengan pendidikan ataupun dunia usaha. Pekerja sosial dalam perencanaan pelaksanaan reintegrasi melakukan beberapa kegiatan di antaranya penyiapan dokumen klien, pembahasan kasus, pembuatan rekomendasi, dan merencanakan alternatif kebijakan serta langkah yang akan diambil bagi kepentingan klien, keluarga dan masyarakat. Penyiapan masyarakat dalam perencanaan reintegrasi tidak dilakukan berdasarkan pernyataan kedua informan yang menyatakan bahwa perencanaan yang dilakukan lebih memfokuskan menyiapkan klien dan keluarga.

\section{Pelaksanaan Reintegrasi}

Pekerja sosial mengungkapkan bahwa pelaksanaan reintegrasi korban penyalahgunaan NAPZA merupakan tahapan terpenting dilaksanakan di mana dilakukannya penyiapan keluarga klien, lingkungan klien dan utamanya diri klien untuk kembali ke masyarakat agar mampu berfungsi sosial. Kemudian penerapan family support group yang dilakukan di IPWL Bumi Kaheman kini sudah berjalan dan dilakukan rutin satu bulan sekali dan jika tidak memungkinkan paling tidak dilakukan satu kali dalam masa program. Pelaksanaan reintegrasi ini juga dilakukan secara terpisah dan berbeda antara klien yang melakukan proses rehabilitasi rawat inap dengan yang rawat jalan. Pelaksanaan reintegrasi bagi klien rawat inap hanya pada pelibatan orang tua dalam penyiapan klien untuk kembali ke masyarakat. Jadi, dalam hal ini pekerja sosial tidak sampai kepada penyiapan masyarakat atau lingkungan tempat tinggal klien dan hanya sampai penyiapan kepada keluarga dengan memberi pemahaman.

\section{Pengakhiran Reintegrasi}

Pekerja sosial mengungkapkan melakukan pengakhiran reintegrasi dengan berpartisipasi pada umumnya dengan tidak melupakan tugas sebagai pekerja sosial. Kegiatan pengakhiran dilakukan secara seremonial formal. Kegiatan tersebut berupa pelaporan pekerja sosial ke lembaga hasil pengamatan dan pencatatan, kemudian pengembalian klien pada keluarga dengan mengisi serta menandatangani lembar terminasi. Kegiatan pengakhiran reintegrasi di IPWL Bumi Kaheman lebih sering dilakukan di lembaga. Kemudian terkait waktu pengakhiran reintegrasi berdasarkan pernyataan informan 
yang mengungkapkan bahwa pengakhiran dilakukan selang waktu beberapa hari dari pelaksanaan reintegrasi.

\section{Dukungan yang Didapatkan Peksos}

Berdasarkan hasil wawancara didapatkan bahwa dukungan yang didapatkan pekerja sosial dalam proses reintegrasi dibagi menjadi dua yakni dukungan moril yang berupa sokongan batin dan dukungan materiil yang diberikan dalam bentuk dana penyokong pelaksanaan reintegrasi yakni berupa uang. Dukungan yang didapatkan pekerja sosial berasal dari pegawai maupun lembaga IPWL Bumi Kaheman dan Kementrian Sosial

\section{Hambatan yang Dihadapi Peksos}

Berdasarkan hasil wawancara diketahui bahwa hambatan yang dialami pekerja sosial adiksi selama melaksanakan proses reintegrasi korban penyalahgunaan NAPZA di IPWL Kaheman dibagi menjadi dua bagian yakni faktor internal dan faktor eksternal. Faktor internal ini meliputi diri klien yang terkadang cukup sulit untuk melakukan perubahan sehingga memperlamban proses penyiapan klien untuk kembali ke masyarakat. Kemudian yang kedua ada faktor eksternal yang di bagi lagi menjadi dua faktor yakni faktor keluarga dan faktor lingkungan gaul klien yang tidak dapat dihindari dan menjadi salah satu faktor penghambat untuk klien kembali lagi kepada masyarakat atau lingkungannya.

\section{Harapan Peksos Terhadap Proses Reintegrasi}

Berdasarkan hasil wawancara diketahui bahwa pekerja sosial memiliki harapan yang menunjang agar proses reintegrasi korban penyalahgunaan NAPZA dapat berjalan dengan lancar. Kerja sama dalam kelompok atau team sangat dibutuhkan dalam proses reintegrasi, sebab kemampuan bekerja dalam kelompok untuk melaksanakan proses ini mampu mempermudah jalannya proses dan mewujudkan pelaksanaan reintegrasi yang baik. Dukungan lebih dari masyarakat juga sangat amat membantu pekerja sosial dalam proses mengembalikan klien ke lingkungan masyarakat. Terpenuhinya harapan pekerja sosial juga dapat meningkatkan pelayanan pekerja terutama dalam proses reintegrasi.

\section{PEMBAHASAN}

Berdasarkan deskripsi hasil penelitian dari aspek persiapan reintegrasi, asesmen reintegrasi, asesmen pada proses reintegrasi, perencanaan pelaksanaan reintegrasi, pelaksanaan reintegrasi, pengakhiran reintegrasi, dukungan yang didapatkan pekerja sosial, hambatan yang dihadapi pekerja sosial dan harapan pekerja sosial terhadap proses reintegrasi, maka selanjutnya akan diuraikan pembahasan hasil penelitian meliputi analisis hasil penelitian, analisis masalah, analisis kebutuhan dan analisis sistem sumber.

\section{Analisis Hasil Penelitian}

\section{a. Persiapan Reintegrasi}

Berdasarkan petunjuk teknis reintegrasi korban penyalahgunaan NAPZA (2019:6) persiapan reintegrasi meliputi penyiapan Korban Penyalahgunaan NAPZA (KPN), penyiapan keluarga, penyiapan pendidikan, penyiapan masyarakat dan penyiapan dunia usaha/kerja.

Pada persiapan reintegrasi di temukan terjadinya penyiapan klien dan penyiapan keluarga. Sedangkan penyiapan masyarakat tidak dilakukan. Pada penyiapan klien, pekerja sosial melakukan pemberian materi, pemberian terapi dan pelatihan vokasional. Pada penyiapan keluarga pekerja sosial melakukan home visit dan Family Support Group (FSG). Pada tahap ini pekerja sosial berperan sebagai fasilitator yakni memfasilitasi klien untuk 
berpartisipasi dan mengikuti pelatihan vokasional. Menyiapkan dan memfasilitasi pertemuan keluarga yakni kegiatan FSG. Selain itu pekerja sosial juga berperan sebagai pendidik yang mempersiapkan klien, orang tua ataupun keluarga dengan peningkatan kesadaran, memberikan bimbingan, pengetahuan dan pemahaman.

\section{b. Melakukan Asesmen dalam Proses Reintegrasi}

Menurut Rianda dalam Ensiklopedia Social Review (2019:70) asesmen lanjutan merupakan asesmen klien yang tidak hanya dilakukan pada saat masuk program terapi rehabilitasi, namun perlu diulang pada kurun waktu selama dia berada dalam program dan ketika yang bersangkutan selesai mengikuti program. Maka pada saat mempersiapkan pelaksanaan reintegrasi tahap melakukan asesmen lanjutan kepada klien diperlukan untuk melihat kemajuan maupun progres dari klien sehingga didapatkannya informasi terbaru terkait klien. Pada tahap ini pekerja sosial melakukan asesmen pada klien dan keluarga. Sedangkan asesmen pada masyarakat tidak dilakukan. Pada tahap ini pekerja sosial memberikan pertanyaan verbal secara langsung dengan menggunakan instrumen pertanyaan. Selain itu pekerja sosial juga memonitoring dan observasi baik kegiatan klien saat menjalani rehab maupun hubungan keluarga dengan klien. Pada tahap ini pekerja sosial berperan sebagai pemungkin yakni melakukan pengungkapan masalah/ penyingkapan awal, eksplor lebih dalam perasaan klien dan mengajak maupun mendorong klien untuk memilih tindakan yang dilakukan berkaitan dengan pemecahan masalah. Pendekatan yang digunakan sebagai pemungkin adalah konseling dengan klien, maupun keluarga.

\section{c. Perencanaan Pelaksanaan Reintegrasi}

Menurut Prihatin dalam bukunya (2009:40) Perencanaan merupakan arah dan pedoman setiap tahapan kegiatan yang harus dilalui atau route map kegiatan kearah tujuan, sasaran, dan target yang sudah di tetapkan. Pada perencanaan reintegrasi pekerja sosial melakukan penyiapan klien, penyiapan keluarga dan kemudian penyiapan masyarakat lagi-lagi tidak tidak dilakukan. Pada penyiapan klien, pekerja sosial merencanakan pelaksanaan reintegrasi melalui kegiatan Case Conference (CC) dan pada penyiapan keluarga, pekerja sosial melakukan persiapan melalui homevisit. Pada tahap ini pekerja sosial berperan sebagai perencana yakni merencanakan segala keperluan terkait proses reintegrasi yang mencakup penyiapan klien, penyiapan keluarga, penyiapan pendidikan dan penyiapan dunia usaha/kerja dan perantara yakni penghubung dengan lembaga/sumber yang berkaitan dengan proses rehabilitasi sosial. Penghubung dengan stake holder di tempat tinggal klien untuk mempersiapkan penerimaan kembali klien ke lingkungan masyarakat.

\section{d. Pelaksanaan Reintegrasi}

Menurut Nurdin Usman dalam bukunya (2002:70) pelaksanaan adalah suatu tindakan atau pelaksanaan dari sebuah rencana yang sudah disusun secara matang dan terperinci, implementasi biasanya dilakukan setelah perencanaan sudah dianggap siap. Secara sederhana pelaksanaan bisa diartikan penerapan. Pelaksanaan ini dilakukan dengan tidak melupakan mekanisme maupun sistem yang sebelumnya sudah di rencanakan pada tahap perencanaan pelaksanaan reintegrasi korban penyalahgunaan NAPZA.

Pada pelaksanaan reintegrasi yang dilakukan untuk penyiapan klien adalah 
bimbingan sosial dan pelatihan vokasional. Sedangkan pada penyiapan keluarga diselenggarakannya kegiatan FSG namun pada tahap ini tidak dilaksanakannya penyiapan masyarakat. pada tahap ini pekerja sosial berperan sebagai pendidik yakni memberikan pengetahuan, pemahaman dan informasi terkait narkotika baik ke keluarga maupun klien, pembela yakni memperjuangkan hak klien dengan memberikan penjelasan dan pengertian kepada keluarga mengani rehabilitasi sosial di lembaga, kemudian hasil yang didapat dalam melaksanakn kegiatan dan tidak memberikan stigma negatif kepada klien, fasilitator yakni berdiskusi, sharing, dan tanya jawab terkait kondisi dan perkembangan klien selama menjalani rehabilitasi dengan mempertemukan seluruh elemen dalam sebuah forum, pemungkin yakni membantu menemukan kekuatan klien agar dapat mampu berfungsi sosial kembali saat di lingkungan masyarakat dan perantara yakni menghubungkan klien dengan sistem sumber yang berhubungan dengan penyiapan pendidikan ataupun penyiapan dunia usaha/kerja, bergantung dengan kebutuhan klien.

\section{e. Pengakhiran Reintegrasi}

Pada tahap ini pekerja sosial melakukan pengakhiran pelayanan dengan menyerahkan klien ke keluarga dan penandatanganan lembar terminasi. Kemudian pekerja sosial juga melakukan pencatatan dan pelaporan ke pada pihak lembaga terkait proses reintegrasi klien. Pekerja sosial dalam tahap ini berperan sebagai manajer kasus yakni memfasilitasi klien untuk memanfaatkan pelayanan yang sudah disediakan dan administrator yakni melakukan pencatatan, menyelesaikan laporan dan melakukan pelaporan.

\section{Analisis Masalah}

Berdasarkan hasil penelitian yang dilakukan dapat digambarkan bahwa belum optimalnya peran yang dilakukan pekerja sosial dalam melakukan proses reintegrasi korban penyalahgunaan NAPZA di IPWL Bumi Kaheman terutama pada penyiapan masyarakat. Maka berdasarkan hasil penelitian dan analisis masalah, peneliti melihat terdapat kebutuhan yang dapat membantu dalam meringankan permasalahan penyiapan masyarakat dalam proses reintegrasi korban penyalahgunaan NAPZA, adapun kebutuhan yang diperlukan dalam pencegahan masalah peran pekerja sosial adalah optimalisasi peran pekerja sosial. Peneliti menemukan permasalahan yang terjadi pada peran pekerja sosial dalam proses reintegrasi korban penyalahgunaan NAPZA yakni ada pada penyiapan masyarakat. Penyiapan masyarakat dalam proses reintegrasi tidak dilakukan oleh pekerja sosial karena keterbatasan dana yang dialokasikan pemerintah dan masih terbatasnya dana yang dimiliki lembaga yang menjadikan penyiapan masyarakat tidak dapat dilakukan. Hal tersebut menunjukkan bahwa anggaran merupakan salah satu faktor yang mempengaruhi kurang optimalnya peran pekerja sosial dalam penyiapan masyarakat pada proses reintegrasi. Maka kebutuhan yang diperlukan dalam menangani kekurangan tersebut adalah optimalisasi peran pekerja sosial dalam penyiapan masyarakat melalui peningkatan kapasitas lembaga pekerja sosial.

Peningkatan kapasitas lembaga pekerja sosial merupakan upaya alternatif untuk membantu mengoptimalisasikan peran pekerja sosial dalam penyiapan masyarakat yang belum sempat terlaksana. Peningkatan kapasitas lembaga pekerja sosial yang dimaksud yakni kegiatan yang di tujukan untuk meningkatkan 
kapasitas yang dimiliki lembaga tempat pekerja sosial bernaung, sehingga diharapkan lembaga mampu mengatasi proses reintegrasi pada penyiapan di masyarakat dengan mengajak masyarakat lebih menerima dan tidak memberikan stigma negatif terhadap korban penyalahgunaan NAPZA ketika kembali ke lingkungan sosialnya. Peningkatan kapasitas lembaga pekerja sosial dilakukan dengan cara memberikan edukasi terkait reintegrasi korban penyalahgunaan NAPZA terutama dalam hal penyiapan masyarakat.

\section{Analisis Sistem Sumber}

Sumber adalah segala sesuatu yang dapat digunakan untuk memenuhi kebutuhan dan memecahkan masalah. Sistem sumber yang dapat dimanfaatkan oleh pekerja sosial dalam memenuhi kebutuhan dan mengatasi permasalahan yang dirasakan, terbagi menjadi 3 bagian. Menurut Pincus dan Minahan dalam Dwi Heru Sukoco (2011) terdapat tiga klasifikasi sistem sumber yang dapat dimanfaatkan, yaitu:

\section{a. Sistem Sumber Informal}

Sistem sumber ini dapat berbentuk keluarga, teman sejawat, kerabat, tetangga, ataupun orang lain yang bersedia memberikan bantuan. Sumber informal yang dapat dimanfaatkan berupa dukungan emosional, kasih sayang, nasihat ataupun motivasi dan informasi serta pelayanan-pelayanan untuk mendukung pekerja sosial dalam melalui proses reintegrasi korban penyalahgunaan NAPZA.

\section{b. Sistem Sumber Formal}

Sistem sumber formal adalah sumber yang dapat memberikan bantuan atau pelayanan langsung kepada para anggotanya. Sistem sumber tersebut yang dapat menyediakan bantuan kepada anggotanya dalam suatu organisasi untuk bernegosiasi dan memanfaatkan sistem sumber kemasyarakatan. Sistem sumber formal yang dapat dimanfaatkan oleh pekerja sosial adiksi yaitu Ikatan Pekerja Sosial Profesional Indonesia (IPSPI) dan Institusi Penerima Wajib Lapor (IPWL) Bumi Kaheman.

\section{c. Sistem Sumber Kemasyarakatan}

Sistem sumber kemasyarakatan adalah sumber yang dapat memberi bantuan kepada masyarakat umum. Sistem sumber yang dimaksud dapat berupa lembaga atau dinas pemerintahan yang ada. Institusi Penerima Wajib Lapor Bumi Kaheman dapat mengakses beberapa sistem sumber kemasyarakatan yang berkaitan dengan proses reintegrasi korban penyalahgunaan NAPZA di antaranya yaitu Dinas Sosial Kabupaten Bandung, Badan Narkotika Nasional Provinsi Jawa Barat, dan Kementerian Sosial Republik Indonesia.

\section{KESIMPULAN}

Penelitian mengenai "Peran pekerja sosial pada proses reintegrasi korban penyalahgunaan NAPZA di IPWL Bumi Kaheman Kabupaten Bandung" ini bertujuan untuk mengetahui bagaimana peran pekerja sosial dalam proses reintegrasi korban penyalahgunaan NAPZA, sehingga di dalamnya membahas mengenai proses reintegrasi yang dilalui oleh pekerja sosial. Hasil penelitian menunjukkan bahwa peran pekerja sosial dalam proses reintegrasi korban penyalahgunaan NAPZA di IPWL Bumi Kaheman sudah dilakukan di setiap prosesnya dengan ditemuinya sembilan peran yang di antaranya adalah peran sebagai fasilitator, pendidik, pemungkin, perencana, perunding, perantara, pembela, manajer kasus dan administrator. Selain itu ditemukannya bagaimana peran pekerja sosial dalam melakukan persiapan, asesmen, perencanaan, 
pelaksanaan dan pengakhiran reintegrasi korban penyalahgunaan NAPZA di IPWL Bumi Kaheman. Pada proses reintegrasi yang diteliti menghasilkan beberapa temuan tema yang di antaranya dalam proses reintegrasi dalam pelaksanaannya dilakukan penyiapan klien, penyiapan keluarga dan penyiapan masyarakat.

Penyiapan klien merupakan kegiatan yang dilakukan untuk menyiapkan korban penyalahgunaan NAPZA kembali ke lingkungan sosialnya. Berdasarkan hasil penelitian sebelum melakukan penyiapan klien, pekerja sosial melakukan persiapan yang mencakup beberapa persiapan di antaranya pemberian materi, pemberian terapi, dan pelatihan vokasional. Kemudian di lanjut dengan melakukan asesmen klien yang dilakukan dengan memberikan pertanyaan verbal secara langsung maupun dengan monitoring dan observasi. Setelah persiapan dan asesmen dilakukan, pekerja sosial kemudian melakukan perencanaan pelaksanaan reintegrasi di dalam forum pertemuan pembahasan kasus atau case conference. Perencanaan dilakukan dengan mempertimbangkan hasil asesmen dan persiapan yang sudah dilakukan di awal proses. Perencanaan sudah dilakukan dan kemudian selanjutnya pelaksanaan reintegrasi. Pelaksanaan reintegrasi pada penyiapan klien yakni mencakup kegiatan bimbingan sosial dan pelatihan vokasional.

Penyiapan keluarga merupakan kegiatan yang dilakukan untuk mempersiapkan keluarga klien agar siap menerima kembali klien dan dapat membantu proses reintegrasi. Berdasarkan hasil penelitian yang didapat bahwa pada persiapan reintegrasi yang dilakukan pekerja sosial dalam penyiapan keluarga adalah kunjungan rumah atau homevisit dan family support group. Kedua kegiatan tersebut dilakukan untuk memberikan pengertian kesiapan keluarga untuk menerima klien sekaligus mengasesmen keluarga terkait latar belakang keluarga, pola asuh yang diterapkan di dalam keluarga tersebut dan hubungan interaksi yang berlangsung antara keluarga dengan klien. Hasil asesmen tersebut yang kemudian menjadi dasar perencanaan pelaksanaan reintegrasi. Pelaksanaan reintegrasi yang dilakukan dalam penyiapan keluarga yaitu melalui kegiatan family support group, dalam pertemuan tersebut keluarga diberikan penguatan dalam kesiapan menerima kembali klien dan pemberian edukasi terkait NAPZA maupun tindakan yang harus dilakukan keluarga ketika klien mengalami kekambuhan.

Penyiapan masyarakat merupakan salah satu faktor penting yang menjadi titik perhatian pada proses reintegrasi ini. Berdasarkan petunjuk dan teknis reintegrasi korban penyalahgunaan NAPZA, penyiapan masyarakat dilakukan dengan melakukan kontak awal dengan tokoh masyarakat, menyepakati rencana kerja, melaksanakan kegiatan penyuluhan/audiensi ataupun sarasehan dan melakukan monitoring. Namun berdasarkan hasil penelitian bahwa penyiapan masyarakat tidak dilakukan oleh pekerja sosial pada proses reintegrasi korban penyalahgunaan NAPZA di IPWL Bumi Kaheman. Pekerja sosial lebih mengoptimalkan pada penyiapan klien dan penyiapan keluarga. Hal ini di akui oleh kedua pekerja sosial yang bekerja di IPWL Bumi Kaheman. Berdasarkan penuturan informan penyiapan masyarakat tidak dilakukan karena memakan proses yang cukup lama dan membutuhkan dana dalam pelaksanaannya. 
Hasil dari penelitian yang dilakukan bahwa peran pekerja sosial dalam proses reintegrasi korban penyalahgunaan NAPZA di IPWL Bumi Kaheman masih belum optimal. Hal ini terlihat dari tidak dilakukan penyiapan masyarakat dalam proses reintegrasi. Penyiapan masyarakat masih belum menjadi bagian dari prioritas dalam pelaksanaannya, sedangkan penyiapan masyarakat merupakan faktor penting yang mendukung keberhasilan reintegrasi korban penyalahgunaan NAPZA. Hal ini terjadi karena klien yang tersebar di berbagai lokasi dan terbatasnya dana yang dimiliki oleh lembaga. Oleh karena itu dalam penelitian ini peneliti mengusulkan program mengenai Peningkatan Kapasitas Lembaga Pekerja Sosial Dalam Penyiapan Masyarakat Pada Proses Reintegrasi Korban Penyalahgunaan NAPZA melalui Educational Group. Program ini dilakukan tentunya menjadi salah satu solusi alternatif bagi lembaga maupun pekerja sosial IPWL Bumi Kaheman dalam penanganan penyiapan masyarakat yakni dengan meningkatkan kapasitas lembaga. Meningkatnya kapasitas lembaga diharapkan dapat mengoptimalkan kembali peran pekerja sosial maupun pelayanan dalam penyiapan masyarakat pada proses reintegrasi korban penyalahgunaan NAPZA.

Hasil dari penelitian yang dilakukan bahwa peran pekerja sosial dalam proses reintegrasi korban penyalahgunaan NAPZA di IPWL Bumi Kaheman masih belum optimal. Hal ini terlihat dari tidak dilakukan penyiapan masyarakat dalam proses reintegrasi. Penyiapan masyarakat masih belum menjadi bagian dari prioritas dalam pelaksanaannya, sedangkan penyiapan masyarakat merupakan faktor penting yang mendukung keberhasilan reintegrasi korban penyalahgunaan NAPZA.
Hal ini terjadi karena klien yang tersebar di berbagai lokasi dan terbatasnya dana yang dimiliki oleh lembaga. Oleh karena itu dalam penelitian ini peneliti mengusulkan program mengenai Peningkatan Kapasitas Lembaga Pekerja Sosial Dalam Penyiapan Masyarakat Pada Proses Reintegrasi Korban Penyalahgunaan NAPZA melalui Educational Group. Program ini dilakukan tentunya menjadi salah satu solusi alternatif bagi lembaga maupun pekerja sosial IPWL Bumi Kaheman dalam penanganan penyiapan masyarakat yakni dengan meningkatkan kapasitas lembaga. Meningkatnya kapasitas lembaga diharapkan dapat mengoptimalkan kembali peran pekerja sosial maupun pelayanan dalam penyiapan masyarakat pada proses reintegrasi korban penyalahgunaan NAPZA.

\section{DAFTAR PUSTAKA}

Adi Fahrudin. (2012). Pengantar Kesejahteraan Sosial. Bandung: PT. Refika Aditama.

Chaplin, J.P. (2002). Kamus Lengkap Psikologi. Jakarta: PT. Raja Grafika Persada Cipta Permana. (2019). Pelajar Pengguna Narkoba di Indonesia tercatat 24 persen dari Total Pengguna Sebanyak 3,37 Orang. Tribun Jabar.id. Diakses dari https://jabar.tribunnews.com/2019/02/26/pe lajar-pengguna-narkoba-di-indonesiatercatat-24-persen-dari-total-penggunasebanyak-337-orang

Departemen Pendidikan Nasional. (2005). Kamus Besar Bahasa Indonesia. Jakarta: Balai Pustaka.

Direktorat Pelayanan dan Rehabilitasi Sosial Korban NAPZA. (2019). Petunjuk Teknis Reintegrasi Bagi Korban Penyalahgunaan NAPZA. Jakarta: Direktorat Jendral Pelayanan dan Rehabilitasi Sosial Departemen Sosial RI 
Hari Harjanto Setiawan dkk. (2018). Faktor Yang Berpengaruh Terhadap Kesiapan Reintegrasi Penyalahguna NAPZA. Jakarta: Pusat Penelitian dan Pengembangan Kesejahteraan Sosial, Kementrian Sosial RI.

Haris. (2012). Peran dan peranan Media Massa Dan Komunikasi. Bandung:PT. pustaka sinar harapan.

Moh.Syafii. (2019). Pengguna Narkoba Tinggi, BNN Optimalkan Peran Keluarga dan Masyarakat. Tribun Jakarta. Diakses dari

https://regional.kompas.com/read/2019/02 /09/23342401/pengguna-narkoba-tinggibnn-optimalkan-peran-keluarga-danmasyarakat

Nurdin Usman. (2002). Konteks Implementasi Berbasis Kurikulum. Jakarta: PT Grafindo Persada

Peraturan Pemerintah Nomor 26 Tahun 2012 Tentang Standar Rehabilitasi Korban Penyalahgunaan NAPZA

Prihatin Tiyanto. (2009). Manajemen Unggul Konsep Dan Aplikasi Untuk Bisnis. Palu: Edukasi Mitra Grafika

Rianda Prima Putri. (2019). Jurnal. Asesmen Sebagai Salah Satu Bentuk Rehabilitasi Bagi Pecandu Narkoba: Sekolah Tinggi Ilmu Sosial dan Ilmu Politik Imam Bonjol

Susilowati.E(2020). ttps://www.researchgate.net/publication/34 223108h7_Penjangkauan_dan_Pendampiin gan_Penyalahguna_narkotika.

United Nations. (2012). Introductory Handbook on The Prevention of Recidivism and The Social Reintegrasi of Offenders. New York: United Nation Office on Drug and Crime. 